\title{
Q fever as a possible cause of bilateral optic neuritis
}

\author{
J. SCHUIL,' J H RICHARDUS, ${ }^{2}$ G S BAARSMA,' AND G J P SCHAAP \\ From the 'Department of Ophthalmology, Erasmus University, Eye Hospital, Rotterdam, and the \\ ${ }^{2}$ Virological Laboratory of the Public Health Service, Rotterdam, The Netherlands
}

SUMMARY A 59-year-old farmer developed a bilateral optic neuritis in the course of an infection with Coxiella burnetii ( $\mathrm{Q}$ fever), resulting in a lasting unilateral blindness. A complete medical (including neurological) evaluation gave no evidence of other possible causes. A possible source of infection was cattle.

$\mathrm{Q}$ fever is an infectious disease caused by Coxiella burnetii. It was supposed to be rare in the Netherlands, but recently 33 cases of $Q$ fever have been described.' In one of these cases an acute infection was accompanied by an optic neuritis. Only a few cases of optic neuritis in the course of $Q$ fever have been described in ophthalmological journals. ${ }^{2-\infty}$ The following case history suggests that the bilateral optic neuritis was caused by an infection with Coxiella burnetit. The evidence is based on both serological and epidemiological data.

\section{Case history}

On 26 June 1983 a 59-year-old farmer consulted an ophthalmologist elsewhere with complete loss of vision of his right eye. The day before he had noticed a loss of parts of his visual field. On 13 June, two weeks before his (subjective) visual complaints, he experienced a period of fever for four days. His temperature rose to $40^{\circ} \mathrm{C}$. He had no complaints related to the respiratory tract, and no headache, myalgia, nausea, or vomiting. During this period there had been urinary retention, for which he was treated by his general practitioner. He had noticed a diminished appetite for food, which lasted a few weeks. The fever was preceded by a week of general malaise and subfebrile temperatures. There was nothing of note in his previous medical history. As a farmer he had occasionally been in contact with pesticides of unknown nature.

CLINICAL INVESTIGATION

On examination on 26 June 1983 the patient had no perception of light in the right eye. Vision in the left

Correspondence to J Schuil, Oogziekenhuis, Schiedamsevest 180, 3011 BH Rotterdam, The Netherlands. eye was 10/10. Funduscopic examination revealed a swollen optic disc on both sides (Fig. 1). The visually evoked cortical potentials of the right eye were not recordable. The potentials of the left eye had normal amplitude and latency. Goldmann perimetry of the left eye gave normal results. Fluorescein angiography gave no additional clues to the diagnosis: on both sides there was pathological leakage of the optic disc without signs of vasculitis.

With the presumed diagnosis of bilateral optic neuritis the patient was treated with parabulbar injections of corticosteroids. At the same tinıe he received orally vitamin $\mathbf{B}_{1}$.

On neurological and internal examination no abnormalities could be found except a slight elevation of protein $(0.69 \mathrm{~g} / \mathrm{l} ;$ normal $0 \cdot 10-0.50 \mathrm{~g} / \mathrm{l})$ and a slight increase in the number of cells in the cerebrospinal fluid (erythrocytes $8 / 3 \mathrm{~mm}^{3}$, polymorph leucocytes $1 / 3 \mathrm{~mm}^{3}$, monocytes $5 / 3 \mathrm{~mm}^{3}$, and lymphocytes $19 / 3$ $\left.\mathrm{mm}^{3}\right)$.

The patient was transferred to the Eye Hospital on 6 July. He still had no perception of light in the right eye. Visual acuity of the left eye was $10 / 10$ (with S $-0 \cdot 50$ ). Eye pressures with applanation tonometry were normal. Both eyes were white, and the anterior segments showed no signs of inflammation or other abnormalities. A right afferent pupillary defect was present. On funduscopy the right optic disc was pale and had blurred margins. A small haemorrhage was centrally located on the disc. The optic disc of the left eye was oedematous. At the 12 o'clock position the retinal vessels showed sheathing. Eye movements were painful, especially those of the right eye.

On 7 July the patient underwent a complete neurological examination at the Department of Neurology. No abnormalities were found. The spinal tap revealed a total protein of $0.92 \mathrm{~g} / \mathrm{l}$. Polymorpho- 

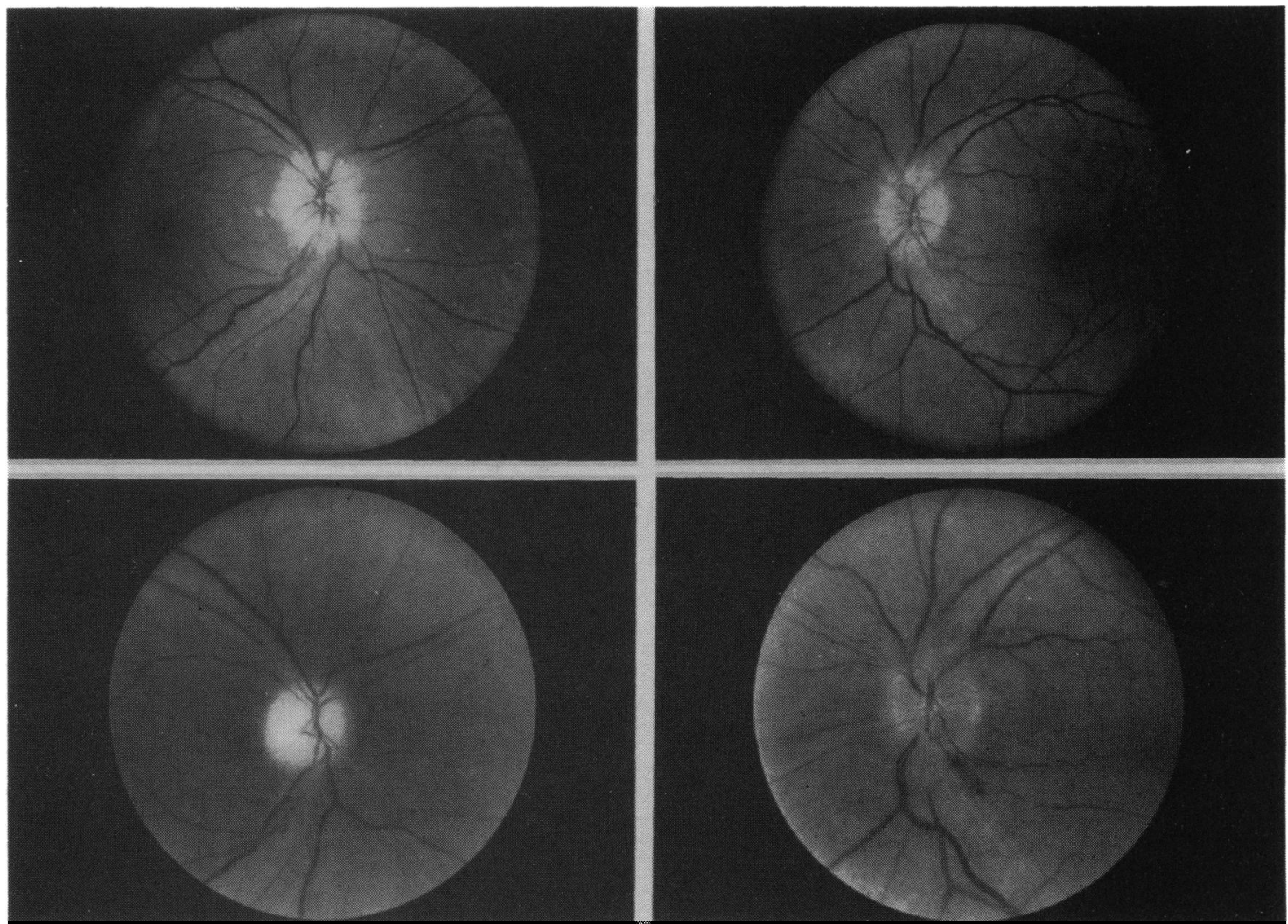

Fig. 1 Fundus photographs of right and left eye on 26 June (above) and 3 August 1983 (below).

nuclear leucocytes were $16 / 3 \mathrm{~mm}^{3}$ and lymphocytes $63 / 3 \mathrm{~mm}^{3}$. CT scan showed both optic nerves to be thickened. The presumptive diagnosis of bilateral optic neuritis was confirmed. In view of the period of fever and the cellular response in the cerebrospinal fluid a viral infection was assumed to be a possible cause of the disease. While waiting for the result of virological examinations, he was treated with a short course of dexamethasone orally.

\section{VIROLOGY}

Virological investigations were performed at the Virological Laboratory of the Public Health Service of Rotterdam. No serological evidence of an infection with Chlamydia psittaci, Mycoplasma pneumoniae, or influenza A, B, mumps, adeno-, herpes simplex, varicella zoster, or cytomegalovirus was found. A rise of the antibody titre to Coxiella burnetii (phase II) in the complement fixation test was found: 1:4 on 29 June 1983 and $1: 16$ on 11 July 1983. The titre of IgM antibodies against $C$. burnetii (immunofluorescence test) was 1:1024 on both dates. The IgG antibodies against $C$. burnetii (immunofluorescence test) rose from 1:1024 on 29 June to 1:4096 on 29 July
1983. The course of the antibody titre, shown in Fig. 2 , was followed during several months. In the cerebrospinal fluid, taken 24 days after the beginning of the visual complaints, no IgM or IgG antibodies against $C$. burnetii was found. From the same sample, inoculated into guinea-pigs, no $C$. burnetii was isolated, nor did the guinea-pigs form antibodies against this organism.

\section{EPIDEMIOLOGY}

This farmer had a horse, a cow, five calves, a dog, cats, and chickens. During the first twelve days of May 1983 he had spent the night in a barn, because the horse he owned had to foal. During the winter time the other animals also stayed in this barn.

In the cow and three calves that were investigated no antibodies against $C$. burnetii could be demonstrated by means of the complement fixation test. On the farm where he usually bought his calves, however, three of 10 cows that were investigated had antibodies against $C$. burnetii. The farmer's wife had no antibodies against $C$. burnetii.

When it became known that this patient suffered from $Q$ fever, he was treated with a daily dose of 100 
Fig. 2 Course of antibodies determined by means of a complement fixation test (CFT) and immunofluorescence test (IgG and IgM) against $\mathrm{C}$. burnetii (phase II) in a patient with acute optic neuritis. Liquor C.S. = time at which cerebrospinal fluid was tapped.

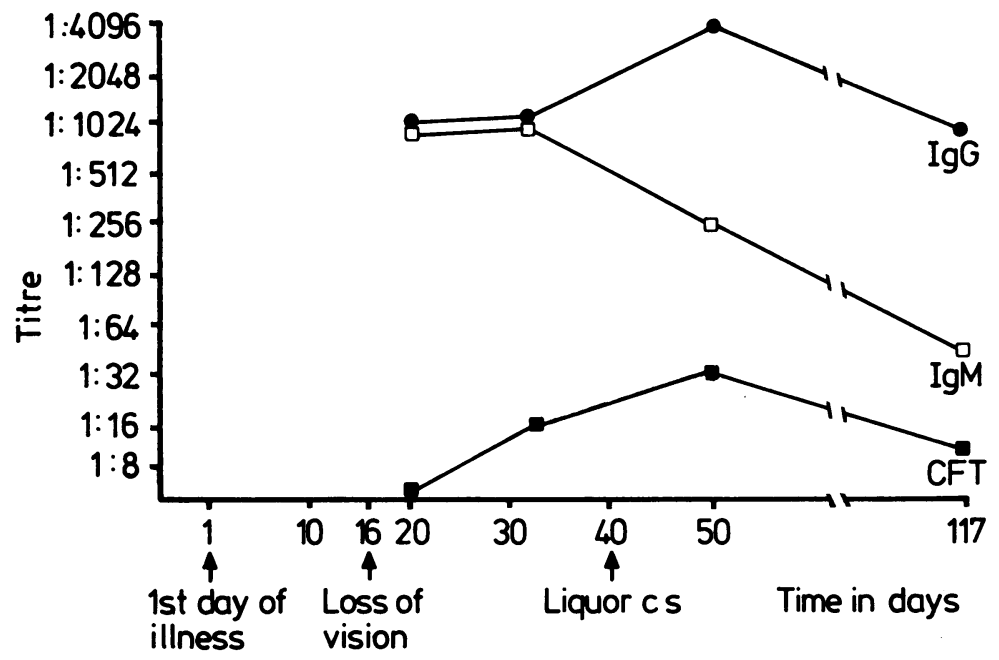

zoster). Bilateral optic disc abnormalities may also be found in disseminated sclerosis or in various intracranial diseases. Neither the history, the medical examination, nor the results of the CT scan showed any evidence of these. A bilateral ischaemic optic neuropathy caused by a temporal arteritis or diabetes mellitus was also ruled out. Serological syphilitic reactions were negative.

Isolation of the causative organism of $\mathrm{Q}$ fever from the cerebrospinal fluid (after inoculation in the guinea-pig or yolk sac of an embryonated chicken egg) could have given a solid proof of the genesis of the optic neuritis. Unfortunately only cerebrospinal fluid taken 24 days after the beginning of the symptoms could be investigated, and inoculation of it was negative. Nevertheless the relationship between the optic neuritis and the $\mathrm{Q}$ fever is made very probable by the course of the antibody titre against C. burnetii. At the beginning of the visual complaints the IgM titre against $C$. burnetii was 1:1024 and had reached its highest point. The IgG titre continued to rise for several more weeks. It appears that the visual loss coincided with the acute phase of the infection.

As to the aetiology of optic neuritis in $Q$ fever two possibilities can be mentioned: a direct effect of the micro-organism on the nerve fibres or an indirect effect on the nerve fibres through a vasculitis."

The serological demonstration of an infection with $C$. burnetii in the cattle of the farm from which the patient purchased his cows and calves gives us an indication of the possible source of infection. If one assumes that the patient was infected during the long stay in his barn (an environment with a potentially high infection risk from dust) an incubation period of $33 \pm 5$ days can be postulated. Although incubation periods of 14 to 21 days are generally found in $Q$ 
fever, periods up to 37 days have been described. ${ }^{12}$ The farmer's wife, who had not slept in the barn, had no antibodies against $C$. burnetii.

In the treatment of $Q$ fever doxycycline $100 \mathrm{mg}$ daily or tetracycline HCL 1-2 g daily is the drug of choice. Generally speaking the prognosis is favourable. Neurological defects are usually temporary. On the other hand four out of five patients reported to have had optic neuritis had a lasting decrease in visual acuity and an optic atrophy. The same was true of our patient: one year after the onset he still had no perception of light in his right eye; his left eye retained a visual acuity of 10/10.

\section{References}

1 Richardus JH, Donkers A, Dumas AM, Huisman J, Schaap GJP. Q-koorts in Nederland; een beschrijving van 33 ziektegevallen waargenomen tussen 1979 en 1983. Ned Tijdschr Geneeskd 1984; 128: 2253-8.
2 Duke-Elder S. System of ophthalmology. London: Kimpton, 1971; 12: 128 .

3 Siegert R, Simrock W, Stroeder U. Uber einen epidemische Ausbruch von $Q$ Fieber in einem Krankenhaus. $Z$ Tropenmed Parasitol 1950; 2: 1-40.

4 Deller M, Streiff EB. Névrite rétrobulbaire et fièvre Q. Bull Mem Soc Fr Ophtalmol 1956; 69: 309-14.

5 Catros $\mathrm{A}$, Hoëll J. Névrite optique axiale bilaterale à fièvre $\mathbf{Q}$. Bull Soc Ophtalmol Fr 1960; 60: 325-30.

6 Fontan P, Desbordes P. Névrite optique et fièvre Q. Ann Oculist (Paris) 1961; 194: 971-8.

7 Christie AB. Infectious diseases. 3rd ed. London: Churchill Livingstone, 1980: 800-12.

8 Clark WH, Lennette EH, Railsback OC, Romer MS. Q-fever in California. Arch Intern Med 1951; 88: 155-67.

9 Masbernard A. Les localisations neurologiques des Rickettsioses. Bull Soc Pathol Exot 1963; 56: 714-51.

10 Spelman DW. Q fever. A study of 111 consecutive cases. Med J Aust 1982; i: 547-53.

11 Pedriel G, Michel A, Guyard M, Hoëll J. Les manifestations oculaires de la fièvre Q. Ann Oculist (Paris) 1961; 194: 957-70.

12 Derrick EH. The course of infection with Coxiella burnetii. Med J Aust 1973; i: 1051-7. 